\title{
Sustaining Performance Habitats for Balinese Animal Effigies in the Anthropocene
}

Made Mantle Hood, Faculty of Human Ecology, Music Department, Universiti Putra Malaysia

made.hood@gmail.com

(C) 2015 University of Malaya. All rights reserved.

Malaysian Journal of Performing and Visual Arts, Volume 1, 2015

\begin{abstract}
Performance contexts for the barong, a mythical animal effigy that symbolizes a Balinese Hindu community's protective spirit, include mock-purification rituals, professional music and dance competitions, and a revival of children's busking barong as street entertainment. In each context, anthropomorphized mythical animals such as boars, tigers, and elephants perform meanings and beliefs that exist along a continuum from revered deity to superficial symbol. In this essay, I draw upon discourses surrounding music ecology and environmental sustainability which serve as background for citing correlations between the physical destruction of Bali's natural environment and urbanization's influence on the mythical animal's traditional performance habitat.
\end{abstract}

Keywords: sustainability, music ecology, barong dance, anthropocene, neo-Hinduism

\section{Defining performance habitats: Human impact on natural environments}

My use of the term 'performance habitat' is intentionally interdisciplinary drawing on the disciplines of ethnomusicology and environmental studies from the perspective of music ecology. Evoking 'ecomusicology', the evolution of a particular performance in a specific surrounding or habitat indicates a codependency, an interrelation and symbiosis between these two constituent parts. Music ecology is an evolving research paradigm that observes 'links between nature and culture' where music as an expression of culture sees these two constituent parts 'constantly permeating one another in a mutual relationship (Harley 1996:2). Parallels between biodiversity and cultural diversity have useful implications for examining sustainable approaches towards empowering dwindling diversity of languages and musics (Grant 2011; 2012). Many researchers are taking up 'applied approaches' in ethnomusicology and related disciplines 'reflecting an international turn towards ecological studies of music' (Bendrups et. al. 2013). Music ecology approaches also demonstrate potential for heritage management scholars to break away from the colonial shackles of conventional safeguarding methods which emphasize 'preservation' rather than observing a 'holistic space of the performing arts' where music, dance and other expressions of culture are best served through the 'facilitation of participatory practices' (Diettrich 2014). Instead of separation into categories of music and dance and ecological approach looks at the 'persistent mutualisms' that dancer and musician share in 'symbiotic relationships' (Hood forthcoming 2016).

Also relating to music ecology and the environment is a recent issue of the Journal of Asian Studies that was partially devoted to the Anthropocene, "...an epoch during which human activity has reached such a level of intensity that it has had a discernable impact on the earth itself" (Ammarell 2014:1005). Bali's natural environment has experienced the full brunt of Indonesia's post-New Order economic development and its human impact through land development. Musicians and other artists have become active agents in promoting environmental awareness particularly since the change to land and real estate laws in the late 1990s that more or less coincided with the island's designation as an autonomous region 
within the nation-state. Land reclamation has been a particular issue of contention drawing lobbyists, real estate developers, religious groups and popular music artists into heated debates and protests over developer's plans to reclaim land for housing development. High-profile Balinese bands such as Superman is Dead, Navicula and Nosstress have performed environmental awareness concerts in Bali and Jakarta supporting Bali Tolak Reklomasi, a protest against the planned reclamation of Balinese wetlands for commercial development in what has been called 'Bali's overdevelopment crisis' (Moore 2015: 300). Music and other performing arts have mobilized a discernable collective consciousness around Bali's environment.

While land reclamation is a relatively new destructive environmental phenomenon of the modern age, the Asian region has a long history of mankind's devastating impact on Mother Nature:

Although the image of Asian 'harmony' with Nature remains a powerful one, the reality is that the region has a very long history of ecosystem transformation by humans. Agriculture (especially wet-rice farming), deforestation, urbanization, advanced structures of economic production and exchange, and coal use in premodern China all had major impacts on the environment. The long history of human impacts on the environment in Asia provides us with a unique opportunity to analyse what are the really important thresholds in the Anthropocene (Hudson 2014: 954).

In this essay, I hope to highlight some of Bali's performance habitat thresholds through examining depleting natural environments that correspond to increased individualism, commercialization and commodification of sacred Balinese animal effigies. Human activity has deforested the densely green areas surrounding many pura dalem, or 'temple of the dead,' to make way for art shops, private residences and tourist attractions. In Bali, building projects and urban expansion have had a significant impact on the island's rapid economic development since 1998 and its subsequent designation as an autonomous region after the fall of the Suharto regime.

The intersecting relationships in the performing arts between animal, human and environment are evidenced in plastic and performing arts in Bali. Louden points out in his anthropological essay on the coexistence of animal/human relations in Bali, "[...] many current socio-ecological models do not fully take into consideration the impacts of human activities...humans are agents of environmental degradation, resource depletion, habitat destruction, and contributors to species extinctions" (Loudon et. al.: 2006:1). Indeed, temples located in densely forested and remote areas of a village often depict in limestone basrelief mythical tigers, elephants, boars and deer. Monkeys occupy the grounds of several busy temples on the island of Bali. These temples such as Uluwatu and Monkey Forest are situated in geographic locations that border human developed areas and natural forest reserves. Postcards of Uluwatu and Monkey Forest Temple contain glossy images of tourists snapping 'selfies' in front of sacred temples while feeding playful monkeys.

However, despite the appearance of peaceful cohabitation, these temples are sites for real conflict and contestation over the environment and reflect the ever-increasing human impact on Bali's ecosystems. The sanctity of temple environments and its surrounding ecosystems - including the very macaque monkeys that inspire Balinese Ramayana performances - are in dire need of sustainability measures. Here, boundaries between human and animal worlds often collide with for many may be considered disastrous consequences. In one study it was found that, "[...] macaques in some locations are hunted, eaten, captured and illegally sold to animal dealers [...]" (Loudon et. al.: 2006:1) evidencing that the intersecting relationships between animal, human and environment are under increasing pressure. Stories of murdered monkeys have direct and real consequences for the ongoing maintenance of performing arts resources. Why? Because Balinese artists have always drawn on nature and the environment and its flora and fauna as inspiration for artistic creation. With the onset of the anthropocene, these real-life episodes of environmental contestation have ramifications for the continuity of Balinese performing arts habitats. 


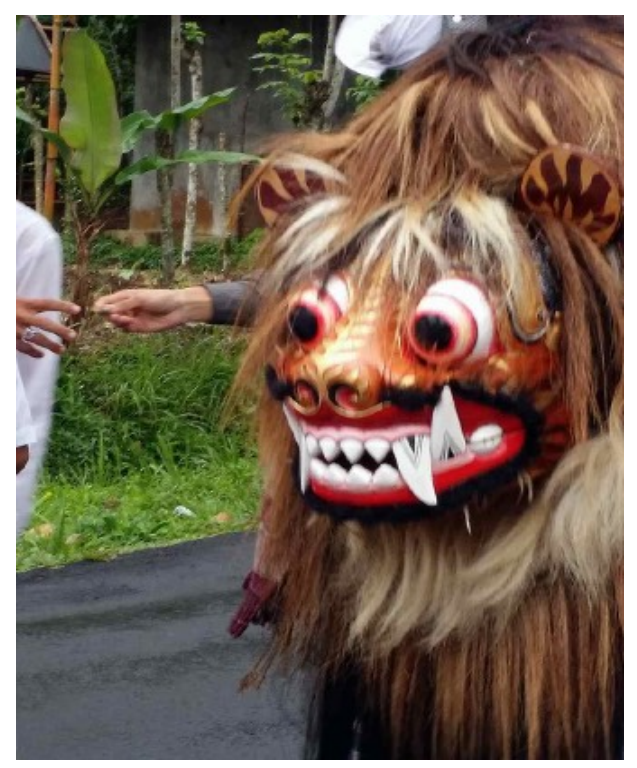

Figure 1. The anthropomorphic effigy of a tiger called barong macan from the highlands of Bali in the district of Bangli.

Many communities in Bali's city centre of Denpasar cut their trees down around their temples long ago, but still maintain barong rituals today. And there has been an increased awareness among Balinese of the need to sustain their island's bio-diversity (Maxim et. al. 2003). For this reason, many Asian communities have adapted strategies to sustain their ecologies. Mark Hudson says that, "the study of Asia can certainly contribute to our understanding of the local contextualization of systems of adaptive learning, providing us with case studies of long-term strategies for sustaining diversity" (Hudson 2014:955). I am interested in how the Balinese employ 'systems of adaptive learning' for sustaining the belief in the barong as mythological animal who serves as a protective spirit in their communities.

Animal and human relationships in Asia have co-evolved so it is not surprising to see enduring depictions of animals in Southeast Asian performing arts. Looking specifically at animal and human relations in Asia, Roel Sterckx in his book, The Animal and the Daemon in Early China (2002), notes that Han dynasty Chinese manuscripts classified animals based not on biological characteristics but rather by their "use within human society" and their "role in social and religious ritual" (Sterckx 2002: 336). Animals were considered to have blood and chi (energy) flowing in their veins. Human and animal were not of separate species but rather considered co-inhabitants of shared territories and environments.

This meant that, like humans who have social hierarchies, animals were also considered to have a kind of social zoology. Dragons, eagles and tigers ranked towards the top of this hierarchy and became the symbols of their human counterparts with kings, rulers and dignitaries. In modern-day Japan, belief in animal spirits has increased in the face of disintegrating traditional families and weakening ties to established religions. Shimazono observes that "spiritualist practices and spirit beliefs are particularly compatible with [Japan's] postmodern world" (Shimazono in Ambros 2010:37).

To see what is compatible with Bali's postmodern world, I now present three new performance habitats: mock purification rituals; drum and dance competitions; and children's busking street entertainment (or what I call 'baby barong'!)

\section{Post-modern purification rituals}


In the context of temple anniversary ceremonies, a barong takes on the role of protagonist in theatrical performances and provides both ceremonial equilibrium and inspiring entertainment for a community. In terms of ceremonial equilibrium, a barong is referred to as sesuunan, a term that indicates a consecrated ritual effigy embodied by a revered protective spirit. During theatrical performances of dramatic stories, the animal effigy is featured as the protagonist in a fourteenth-century East Javanese theatrical story of black magic called Calonarang, revolving around a widow witch and King Airlangga of Kediri. In this performance habitat, the sesuunan will tedun masolah or 'descend to dance' and serve as protagonist warding off evil to provide balance and ceremonial equilibrium. The barong's features include large fangs, bulging eyes and snapping jaws designed to be intentionally fierce and threatening. A barong's appearance is both revered and feared as a protective 'mascot' of a community. During periods of pestilence, disease or famine in a village, this type of barong would defend against the omnipresent negative energies of Ratu Gede Mecaling and his evil disciples who are thought to wreak havoc in villages and towns. This is a principal reason why barong have always been melancaran or paraded through village streets after midnight as protection against black magic and other mischievous forces.

During theatrical performances of a more secular nature - such as music and dance competitions, tourist shows, or other non-religious events - a barong mask and costume are not consecrated as a ritual barong sesuunan. Rather the animal effigy is merely a replica of a ritual barong that has been popularized since the onset of Balinese cultural tourism in the early twentieth-century. Although serving only as a replica, dancers who adorn a secular barong costume very often make personal prayers and offerings to ancestral and protective deities to safeguard and ensure a successful performance. Here the inherent binary between sacred and secular performance habitat are partially blurred. In cases where performers perceive potential risks, precautionary measures are taken to safeguard against malicious spirit possession, the offending of honoured ancestors, or performing poorly in public, even though their performance is for tourists.

Since the fall of the New Order, newly formed religious sects in Bali demonstrate Hinduism's increased individualism within the island's syncretic approach to faith and belief. Neo Hindu-sects such as Resi, Sai Baba, Siwa Shidanta, Buddha and Brahma have set up pasraman or religious schools, which not unlike their pasantren Islamic counterparts, typically unite behind a single spiritual leader. Pasraman are very often guru-centric institutions led by a religious figure who receives absolute devotion from his followers. Traditionally black magic, ghosts, plague and illness were attributed to forces beyond the control of Balinese Hindus and attributed to supernatural forces that required communal action to restore balance. Today many Balinese Hindus have turned away from customary healers to seek solutions that no longer require communal consensus. Although still central to religious life, community-based rituals no longer serve all the needs of a much more decentralized, faith-based demographic, particularly among a modernizing urban middle class. It may be said that post-New Order organized religions such as Balinese Hinduism no longer have a monopoly as established institutions. In the past two decades, an amalgam of post-modern spiritualist practices has existed on the island. Reiki, Yoga, Sai baba, Siwa Shidanta and other religious sub-divisions have established strong followings. As in other parts of Asia, it may be observed that, "[...] such spiritualist practices and spirit beliefs are particularly compatible with the postmodern world because they work well within the context of disintegrating traditional family structures and weakening ties with established religious institutions" (Shimazono in Ambros 2010: 37). Indeed, Balinese family structures are being tested by Bali's rapid thrust towards modernity. It is not surprising then, that Balinese Hinduism's decentralization coincides with a plurality of approaches to spirituality and faith.

In recent years, these pasraman religious sects - with the participation of the urban middle class, rural villagers, and other segments of society - have employed the sesuunan icon of the barong animal effigy and inadvertently applied new meanings to it in an entertainment version of calonarang theatre. Using a mock or costume-only form of the barong, the new entertainment calonarang is staged in non-ritual contexts. These include community fundraisers, village temple anniversary celebrations, and even the annual Bali Arts Festival. Of course live audiences watch and even participate, but many of these performances are 'mediatized' and consumed passively by audiences on local television stations or via YouTube. 
One video clip posted on YouTube (www.youtube.com/watch? $\mathrm{v}=\mathrm{QaMBnP} 3 \mathrm{~W} 6 \mathrm{NI}$ ) is from Mandala Suci, a neo-Hindu sect and religious school that has organized its own mock dramatization of the Calonarang purification ritual. Two elements are worthy of note in this clip: dramatic flow and individualism. First, in the video we see the Manadala Suci leader preaching about his abilities to challenge and defeat black magic ghosts (leyak). The length of his sermon is unheard of in traditional calonarang lasting for over fifteen minutes in an attempt to win support from potential followers. Members of Manadala Suci lie on the ground like corpses receiving funeral offerings. Second, his message is about how the powers of an individual will overcome evil.

Why is the performance of stories about black magic, spirit possession and resurrection popular in Bali today? Does it reflect audience preference for dramatizing real-world uncertainties and insecurities associated with a rapidly modernizing twenty-first-century Bali? What is clear is that the popularity of calonarang has little to do with the traditional protagonist, i.e., the barong in its usual performance habitat: the temple of the dead. Rather the new protagonists are leaders of 'aliran agama Hindu': neoHindu sects who have appropriated the calonarang drama and scripted themselves as spiritual saviours and restorers of balance during times of uncertainty.

That said, to the eyes of the spectator, the barong in its new post-modern purification ritual still symbolizes the restoration of spiritual harmony, balance and calm. In times of political, economic and social instability and uncertainty, it is not surprising to see an increase in the performance of 'mock' purification rituals. Using the barong in this manner may allow participants to feel an emotional release and inducing calm after the re-enactment of the ritual, without bearing the enormous cost of making traditional offerings or the complex coordination necessary between village networks. Participants can temporarily allay their fears in the presence of their mythological animal, even if that barong is "just a barong," and not their sesuunan protective spirit. What is crucial, however, is how these symbols are manipulated by neo-Hindu sects like Mandala Suci as empty effigies that serve their rather selfish agendas.

\section{Drum and barong competitions}

The second performance habitat considered in this essay for the barong is the realm of competition for professional musicians and dancers. Here virtuosity, individual talent and skill trump any notions of spirituality or communal devotion associated with the barong's traditional ritual setting. In this context, highly trained dancers and drummers compete for prizes and awards in competitions called bapang barong. Participants also compete for less tangible, but no less significant awards in the form of cultural capital, such as reputation, status, peer-admiration and bragging rights.

In July 2013, the village of Singapadu hosted competing bapang barong performers from the districts of Gianyar, Tabanan, Denpasar, Badung and Klungkung. Competitors were between 15 and 25 years old. The competition lasted for two days and a pre-competition screening and selection process was overseen by competition committee chair, Kadek Nova Prasetya. Twenty-two participants from five districts took part. The competition, although secular in nature, was held at the Tenggaling Penguku-ukuran Dalem Temple at the community ward of Sengguan, historically one of the most significant village centres for the development of barong dance (Bandem 2014: 66).

Dancers were judged on technical skill, choreography, and spontaneity. Drummers were ranked according to phraseology of drum patterns, dexterity, and rhythmic virtuosity. Although an entire orchestra of musicians accompanied the barong dance, only the lead drummer's performance was judged. While a barong requires two dancers to operate the heavy costume, the jury scrutinize the lead dancer controlling the head. 
It has been shown that competition does motivate communal rivalry and creativity and may be considered, "community-based occasions for creating, experiencing and participating" (Dudley 2003:12). Historically Balinese performing arts have thrived precisely because competitive rivalries exist between local and regional gamelan troupes. However, competitions also have the potential to dictate standards and require a diverse selection of participants who may come to the competition with their own regional 'musical diversity' (Hood 2010), only to conform to predetermined performance criteria. From the perspective of prescribing formal parameters and competition criteria, Frank Gunderson observes that music competitions can, "[...] either legislate stagnant uniformity [...] or encourage creativity and stylistic sophistication” (2003:8).

For example, in barong competitions, it is virtually a given that competitors demonstrate their acrobatic skills. It is not uncommon to witness the barong snap its jaws and jump several feet into the air to achieve dramatic climax in its choreography. This standardized choreographic movement is quite a feat considering two dancers must coordinate well in order to heft their heavy costumes and wooden masks in the air precisely at the same time. Inevitably the audience cheers at the end of this portion of the choreography.

Barong's performance habitat in the realm of the professional/elite competition puts the focus on the individual performer more than its communal/functional performance habitat. Appropriately, a drummer in the competition usually dresses differently from the rest of the orchestra in order to draw attention to himself. After competing, barong dancers disrobe, de-mask and reveal their faces to the reception of a roaring applause. The belief in the barong animal as protective spirit and conduit to the ancestors is absent in this context. I observe that the mask worn by the dancer is but a mock image, an empty effigy, a mere prop that carries few associations to placating evil spirits or warding off black magic. In this new performance habitat, the emphasis is on individual virtuosity and technical prowess put on display for peers to simultaneously admire and challenge through the hierarchy of competition.

\section{Busking barong}

Happily, the third performance habitat for the barong represents a revival of a children's art form. It is called barong kedingkling, a kind of street form of village busking in which young boys parade through the village with drums, cymbals, gongs and a miniature version of their community's sacred barong. First documented by Colin McPhee in the 1930s in his book Music in Bali (1966), for decades barong kedingkling has been more or less absent from Bali's performing arts landscape, a result of new diversions: modern toys, television, and other distractions that saw this type of playful re-enactment of ritual almost vanish. But in the last few years, kedingkling has reappeared. It is now found in villages and tourist centres throughout much of the island. The more entrepreneurial children's troupes are found hustling for donations in the popular tourist areas, Sanur, Ubud and Kuta.

However, in December 2014 I witnessed a much more commercial form of kedingkling in a local competition of mini-barong in my home village of Singapadu. The event was sponsored by Alfa Mart, a chain of convenience stores with over 7,000 locations nationwide. Alfa Mart's latest marketing campaign involves organizing cultural events held at their stores across the island. I spoke with Alfa's Marketing Director, Agus Nono from Central Java who was organizing the event. He claimed that by participating, community groups in the immediate vicinity of their stores benefit from the barong kedingkling competition, and called it a situation of 'saling menguntungkan' or mutual benefit, in which competition winners receive prizes and a donation from Alfa Mart. Every month Pak Nono moves his cultural marketing campaign to another strategically located convenience store on the island. He targets an area to exploit its local performing arts as a platform for Alfa Mart brand integration into a community's consumer-based economy. 
Kedingkling is run by youths who command a small battery of gamelan percussion. On this day, groups are set up just outside the Alfa Mart convenience store where curious onlookers might pick up a pack of cigarettes and a cold Coke. Singapadu resident and Mukti community ward member, Komang Ogik serves as lead dancer for his barong bangkal or 'wild boar barong'. It was created and designed to look like their community's sesuunan protective spirit, which is housed in the community ward's temple just down the street from Alfa Mart. Komang is a very skilled dancer. He can execute his pre-rehearsed choreography and still remain calm and collected before jumping on stage, and manipulating his mask's snapping jaws to the delight of a local audience.

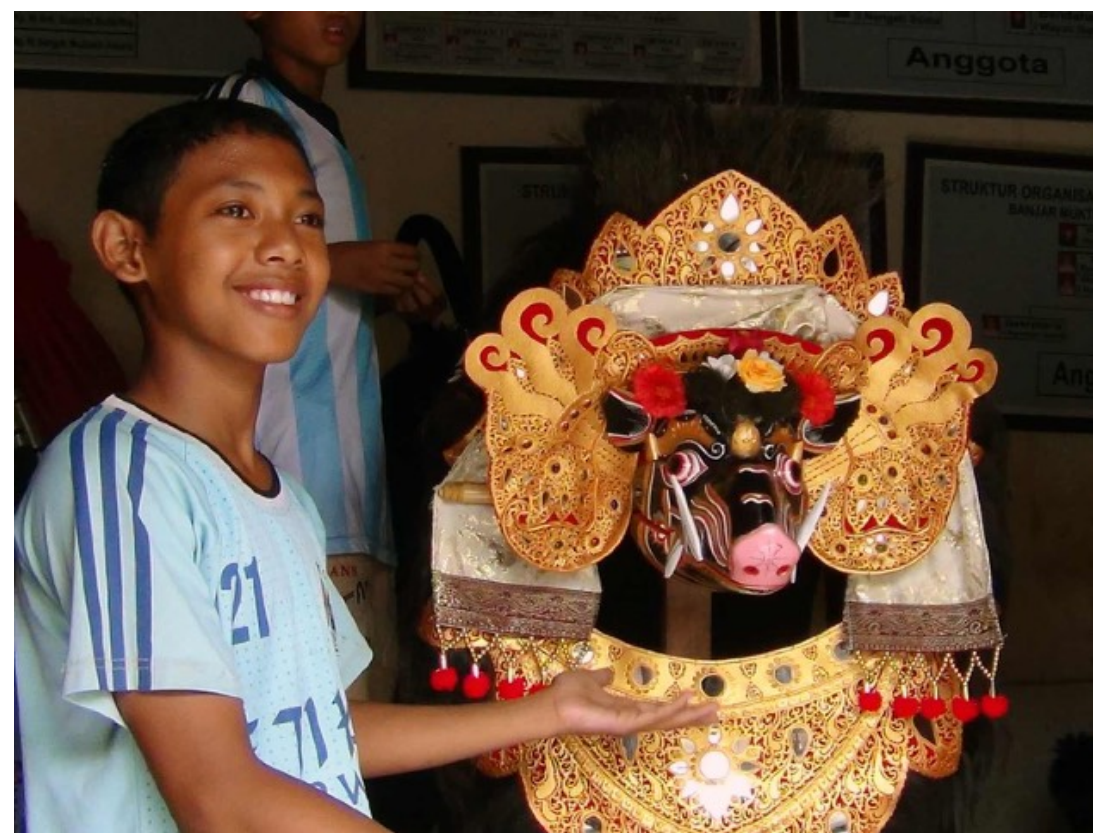

Figure 2. Singapadu resident Komang Ogik poses with the 'boar barong' (barong bangkal) before he adorns it for the Alfa Mart competition. He is the son of masked dancer and Institute Seni Indonesia Denpasar graduate, priest Mangku Ketut Suma.

In the discussion of performance habitat, it is important to recognize that through kedingkling children imitate temple performances. Through their imaginations, they transport themselves to the temple of the dead, and an environment of tombstones, old scary trees, ghosts and goblins. 'Kedingkling as play' replicates a ritual performance habitat in an attempt to duplicate the actions and events children see in that ritual. This is particularly significant for Balinese ritual transmission because mimicry is fundamental to the acquisition and transmission of culture from one generation to the next.

\section{Conclusion: Keeping the 'animal within'}

Traditionally, the barong only inhabited temple grounds, serving as the protective spirit for a community more or less unified under the common belief in its healing ritualistic powers. The barong animal effigy now appears in secular spaces to accommodate the needs of individuals and groups with diverse agendas. The result is what I have called newly formed 'performance habitats' and includes Neo-Hindu calonarang and newly formed professional music and dance competitions. Both allow for the formation of new identities for the barong animal effigy. The barong recontextualized into secular and competitive performance habitats in some instances reduces it to a commodity, an icon, and even a mascot. For 
example, the Neo-Hindu calonarang prioritizes spectacle and entertainment over community and functionality. The barong is no longer the central character and protagonist. In the barong's place are the leaders of neo-Hindu pasraman who act out their abilities on stage to protect their followers against the negative forces of twenty-first century black magic. In these Neo-Hindu calonarang, participants still view the barong as a symbol of purification even though much of the traditional performance habitat of the barong has been literally and metaphorically cut down and paved over.

But all is not doom and gloom for belief in the barong as sesuunan spiritual protector. Kedingkling's performance habitat may be fraught with problems and contradictions such as the commodification and commercialization of Balinese performing arts. Alfa Mart does assert its own agenda by appropriating local culture to push its brand in local villages. But prizes and donations from Alfa Mart for children come with the hope of imprinting more than just 'brand loyalty' from 'baby barong' groups. It may be observed that children's kedingkling activities successfully embed the protective animal spirit within the hearts and minds of young boys and girls who participate in the fun. Imprinting the barong early in a child's life through such play makes the lofty deity of the barong immediately accessible and approachable as an icon of faith. It seems to me this is one of the best ways to keep the 'animal within'. This is the protective animal spirit that has watched over communities for generations. What better way to internalize its meanings for children than to dress up in costume and march through your community as the barong animal itself.

\section{Bibliography}

Ambros, B. (2010). Vengeful spirits or loving spiritual companions? Changing views of animal spirits in contemporary Japan. Asian Ethnology. 69(1): 35-67.

Ammarell, G. (2014). Whither southeast Asia in the anthropocene? Asian Studies. 73(4): 1005-1008.

Bandem, S.W. (2014). Barong kuntisraya: Ikon seni pertunjukan Bali kontemporer. Denpasar: BP STIKOM Bali Press.

Bendrups, D., K. Barney \& C. Grant. (2013). An introduction to sustainability and ethnomusicology in the Australiasian context. Musicology Australia. 35(2): 153-158.

Diettrich, B. (2014). Performing arts as cultural heritage in the Federated States of Micronesia. International Journal of Heritage Studies. 21(7): 660-673.

Dudley, S. (2003). Creativity and control in Trinadad carnival competitions. The World of Music. 45(1): 11-33.

Grant, C. (2012). Analogies and links between cultural and biological diversity. Journal of Cultural Heritage Management and Sustainable Development.

Grant, C. (2011). Key factors in the sustainability of languages and music: A comparative study. Musicology Australia. 33(1): 95-113.

Gunderson, F. (2003). Preface: Contesting tradition: Cross cultural studies of music competition. The World of Music. 45(1): 7-10.

Harley, M. A. (1996). "Notes on music ecology: As a new research paradigm". Los Angeles: University of Southern California. Accessed September 20 2015. http://www.wfae.proscenia.net/library/articles/ harly_paradigm.pdf

Hood, M. M. (forthcoming 2016). Persistent mutualisms: Energizing the symbiotic relationship between Balinese dancer and drummer. In K. Stepputatt \& M. A. Nor (Eds.) Sounding the dance, moving the music: Maritime Southeast Asian performing arts in choreomusicological perspective (pp. 1-16). Surrey: Ashgate Press. 
Hood, M. M. (2010). Gamelan gong gede: Negotiating musical diversity in Bali's highlands. Musicology Australia. 32(1): 69-93.

Hudson, M. J. (2014). Placing Asia in the anthropocene: Histories, vulnerabilities, responses. Asian Studies. 73(4): 941-962.

Loudon, J. E. et. al. (2006). The importance of integrative anthropology: A preliminary investigation employing primatological and cultural anthropological data collection methods in assessing humanmonkey coexistence in Bali, Indonesia. Ecological and Environmental Anthropology. 2(1): 1-13.

Maxim, S., I. Hadad \& S. Sitorus. (2003). Building an endowment for biodiversity conservation in Indonesia: The case of KEHATI. New York: Synergos Institute.

McPhee, C. (1966). Music in Bali: A study in form and instrumental organization in Balinese orchestral music. New Haven: Yale University Press.

Moore, R. E. (2015). Indie music in post-bomb Bali: Participant practices, scene subjectivities. Dissertation, Indiana University. Bloomington, Indiana, USA.

Sterckx, R. (2002). The animal and the daemon in early China. SUNY Series in Chinese Philosophy and Culture. Albany: State University of New York Press. 